\title{
Supporting Small Borrowers: ABS Markets and the TALF
}

Bruce Mizrach, Professor of Economics, Rutgers University

Christopher J. Neely, Vice President and Economist

redit markets typically require large-value loans and a way to mitigate risk. Loans for vehicles, credit cards, or student debt tend to be of relatively low value, however, and a single loan itself is individually risky as borrowers may be unable or unwilling to repay the loan. So, until the mid-1980s, these characteristics hindered the development of markets for this sort of credit and also made that credit fairly costly compared with the rates for corporate debt or even mortgages. The development of assetbacked securities (ABSs) in the mid-1980s solved many of these problems and contributed to the great growth of credit to individuals in the past 50 years or so.

An ABS is a structured security whose owner receives coupon and principal payments from the repayment of loans from one of a variety of markets, such as credit cards, auto loans, student loans, or other receivables. ${ }^{1}$ That is, lenders sell the rights to receive loan (or other) payments in the form of a bond. Agarwal et al. (2010) describe how the payments are securitized, tranched (sliced up), and sold to investors. In this way, ABSs convert relatively risky, heterogeneous, low-value assets into safer, homogeneous fixed-income securities that can be traded so that many savers-for example, people or pension funds-can participate in loaning people money for a car or an education. That is, ABSs greatly broaden the lending market for small loans and thus increase their availability and decrease their cost for borrowers. According to the Securities Industry and Financial Markets Association, ABS issuance peaked in 2007 at $\$ 796$ billion.



NOTE: Daily volume of trading in ABS markets from January 2, 2020, through March 31, 2020.

SOURCE: FINRA Trading Reporting and Compliance Engine obtained from Wharton Research Data Services. 
Figure 2

\section{Bid-Ask Spreads in ABS Markets}

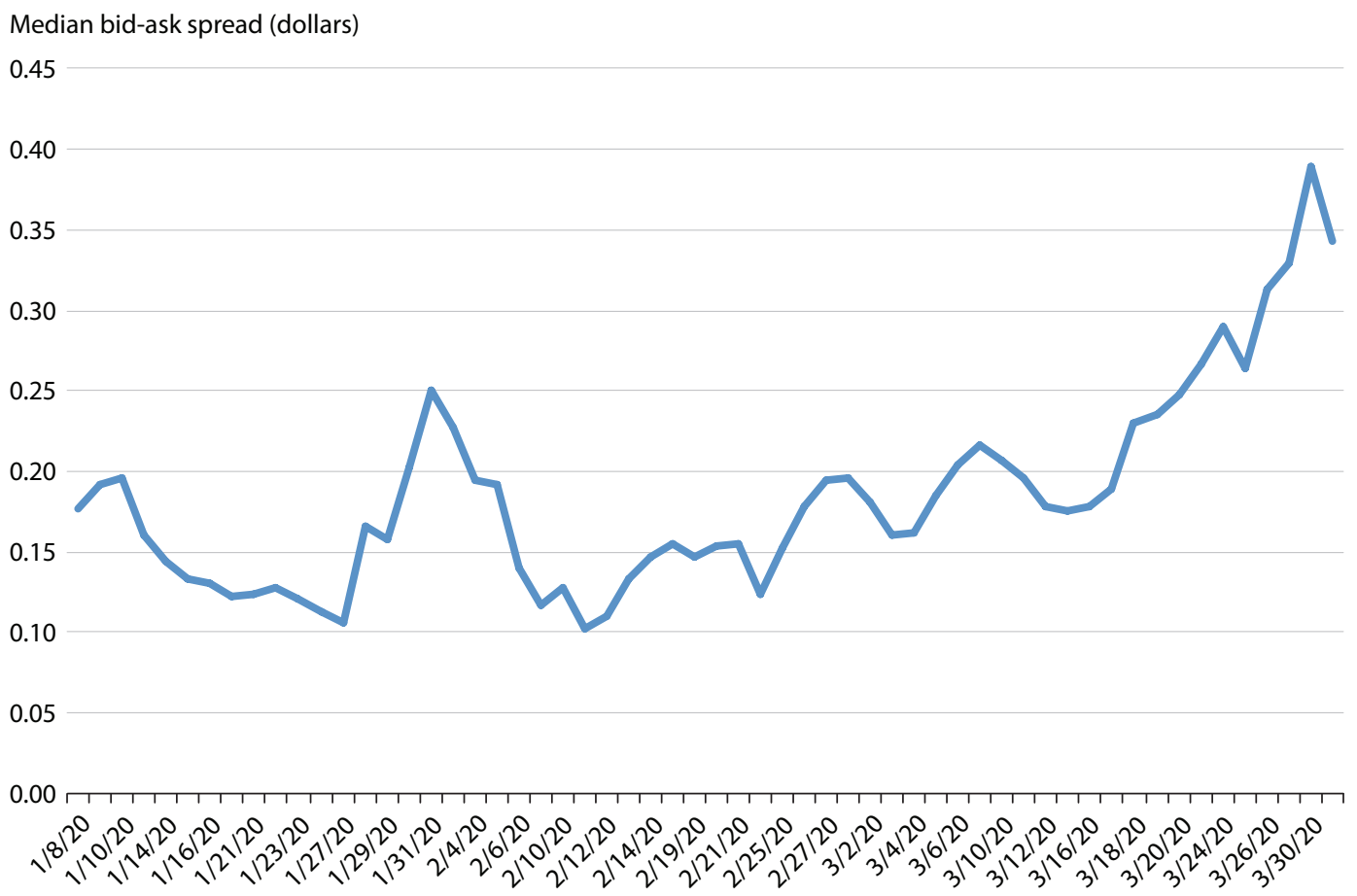

NOTE: The median bid-ask spread in ABS markets from January 2, 2020, through March 31, 2020. The data represent all ABS markets except those backed by credit card, auto, and student loans, which are omitted because they are relatively thinly traded.

SOURCE: FINRA Trading Reporting and Compliance Engine obtained from Wharton Research Data Services.

\section{On March 23, the Federal Reserve established the Term Asset-Backed Securities Loan Facility (TALF) to support consumer and small business lending.}

This essay reports on recent developments in the secondary market for ABSs, particularly on Federal Reserve policy interventions to support such markets. As with other financial markets, ABS markets were shaken by the bad news about the spread of the COVID-19 virus and the unprecedented consequent shutdown of economic activity around the world. Starting in mid-February, uncertainty about the economic situation began driving equity prices down; corporate bond risk spreads began rising strongly in March. Bid-ask spreads began to rise in many markets as uncertainty and fast-moving prices made traders reluctant to risk quoting narrow spreads and having to buy (sell) at a price that was too high (low).

Figure 1 depicts the rising volume of trade in ABS markets during mid-March as traders presumably sought to rebalance their portfolios in light of the new, uncertain environment. This trading peaked during the week of March 16-20, when a series of Treasury and Federal Reserve policy initiatives curtailed some of the worst effects of the uncertainty in financial markets. The policy initiatives did not reduce the enlarged bid-ask spreads in ABS markets, however. Figure 2 shows that those spreads started to rise from the $\$ 0.10$ to $\$ 0.15$ range in late February to a range around $\$ 0.35$ in late March.

To facilitate the functioning of ABS markets and ensure that loans will still be available to consumers, on March 23, the Federal Reserve established the Term Asset-Backed Securities Loan Facility (TALF) under Section 13(3) of the Federal Reserve Act. ${ }^{2}$ The Fed will finance a special purpose vehicle (SPV) to initially loan up to $\$ 100$ billion to issuers of AAA-rated ABSs backed by a variety of newly and recently originated loans to fund a variety of lending, including small business loans, auto loans, credit card loans, and education loans. The loans are nonrecourse, meaning that the Fed's only way to recover money in the event of a default is to seize the ABS posted as collateral, but the value of that ABS will exceed the value of the loan, which should safeguard against losses. ${ }^{3}$ The U.S. Treasury is seeding the first $\$ 10$ billion from the Exchange Stabilization Fund to cover any losses. ${ }^{4}$ 
Figure 3

Federal Reserve Lending During the First Version of TALF, 2009-14

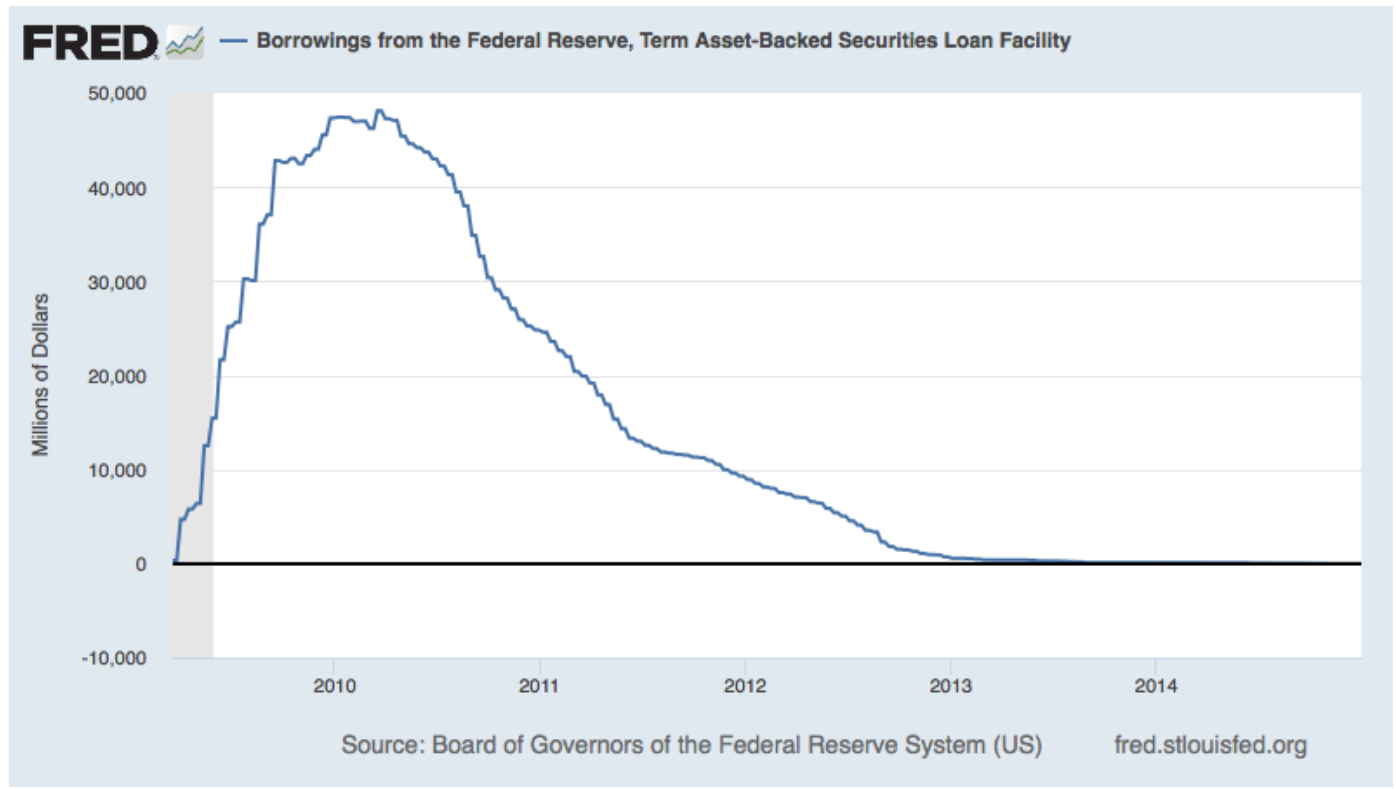

NOTE: Outstanding loan amounts of the 2009-14 version of the TALF. Gray bar indicates recession as determined by the National Bureau of Economic Research.

SOURCE: FRED ${ }^{\circledast}$, Federal Reserve Bank of St. Louis.

The current version of TALF had a very similar predecessor during the 2007-09 Financial Crisis. On November 25, 2008, the FOMC announced the first version of TALF to support the flow of credit to consumers. This facility began lending with terms of up to five years in March 2009.

Figure 3 shows that outstanding loans peaked at just under $\$ 50$ billion in 2010 and almost all loans were repaid by the end of 2012. The facility closed in 2014.

\begin{abstract}
Notes
${ }^{1}$ Mortgage-backed securities, collateralized mortgage obligations, and collateralized loan obligations are not usually considered to be ABSs, but the AAArated tranches of both outstanding commercial mortgage-backed securities and newly issued collateralized loan obligations are TALF-eligible collateral.

2 Section 13(3) of the Federal Reserve Act allows the Board of Governors of the Federal Reserve System, in unusual and exigent circumstances, to authorize Reserve Banks to extend credit to individuals, partnerships, and corporations.

3 The amount by which the collateral exceeds the value of the loan is called a "haircut."

4 In conjunction with the Primary and Secondary Market Corporate Credit Facilities (PMCCF and SMCCF), the TALF will lend up to $\$ 850$ billion, with the U.S. Treasury seeding $\$ 85$ billion to cover any losses.
\end{abstract}

\section{Reference}

Agarwal, S.; Barrett, J.; Cun, C. and De Nardi, M. "The Asset-Backed Securities Markets, the Crisis, and TALF." Economic Perspectives, 2010, 34(4). 